\title{
Gentrification versus structure relocation - how can we preserve a city's cultural heritage?
}

\author{
A.Połtowicz, B. Podhalański \\ Kracow University of Technology, Faculty of Architecture, Department of Spatial Planning, Institute \\ of Urban and Rural Design A-5, Kraków, Poland
}

\begin{abstract}
A number of cities are currently experiencing gentrification at various stages and intensities. Gentrification is a powerful force for economic change, but it is often accompanied by unnecessary demolition of historic buildings that are not included in the monuments registers. This article describes how to identify an area that could potentially undergo or has already undergone gentrification, using the example of the Piasek district in Krakow. It explains how gentrification has intensified in this district since the 1990s. The article also discusses the possibilities of reducing the destructive impact of gentrification on urban space by relocation of a historical building that was initially slated for demolition due to the ongoing gentrification of the area.
\end{abstract}

\section{INTRODUCTION}

Historically, the term 'gentrification' was first used by sociologist Ruth Glass in 1964 while studying class dependencies in selected districts of London. She analyzed how the working class was successively pushed out by the middle class in Hampstead, among other places [1]. Looking for a general, universal definition of this term, we can assume that the gentrification of a given area of a city denotes the pushing out of its residents by the population of higher social and material status, which is also often better educated[2]. Factors that generate this phenomenon are directly associated with the attractiveness of a given district, which carries the potential for revitalisation, new development projects, and the interest of the creative class [3]. These measures bring with them economic change that does not allow previously settled poorer classes to remain in a given area. After a period of the emergence of numerous suburbs around Polish cities, positives in settling in often already depopulated, service and tourism-oriented city centreshave once again been noticed. The re-urbanisation of cities, the influx of a new population wishing to live in exclusive, renovated districts within city centresis closely relatedto the phenomenon of gentrification [4].

Areas that aspire to do so are characterised by proximity of historic city centres, green space of significance in terms of the entire metropolitan area, and often have a rich history and a certain type of spirit, an atmosphere created by its residents. Today, cities are home to all social classes, who, depending on the circumstances, displace each other from certain areas. Social classes have not disappeared in Poland and are intuitively identifiable by society [5]. Gentrification, although it is seen negatively, also has a positive side. In the 
context of the impact of individual districts on the general image of the city, a decayed area can experience a rebirth, elevating the prestige of the metropolis at the regional or state level.

As a part of the contemporary re-urbanisation of city space, gentrification expresses itself in three main aspects. It primarily manifests itself in the spatial dimension via an improvement to the aesthetic of a given place and its technical and economic condition, an increase in property prices and living costs in a given area, as well as in demographic changes [6]. It should be noted that gentrification can also have the opposite character and lead to the re-decay of the area. Gentrification is also a process that occurs naturally and typically is closely linked with revitalisation. Regeneration, although aimed at integration, that is, improving the quality of a given space to the benefit of its residents, often leads to the gentrification of the area [7].

Ultimately, the narrative on gentrification always boils down to the human factor. All aspects of it are reflected in the characteristics of the inhabitants of a particular neighborhood. One must account for how severely it affects the architecture of a given place, often doing so negatively. Taking Krakow as an example, one can clearly state that it manifests itself in the form of aesthetically unpleasant remodeling, vertical expansion, or restoration projects of specific, originally valuable buildings. These measures are possible for a number of reasons, including bad law, legal loopholes, or neglect, resulting in a given building not being listed as a heritage site.

This phenomenon is associated with the negative activity of real estate developers, who are primarily focused on the maximum possible profit and do not see any value in protecting authentic urban framework. The restoration of old buildings is always associated with considerable expenses, which can be ignored by contemporary facades when a building is not a heritage site, thus leading to the removal of architectural detail or the outright demolition of the building to build new urban substance. Krakow is one of many cities on the map of Poland map where, along with developing suburbs, one can observe rising interest in returning to its historical districts.

Since the 1990s, the development of tourism has been slowly forcing the original residents of these areas to move out, giving way to all kinds of services and cultural facilities. However, there are numerous townhouses that are still not restored and are inhabited by their original residents. They are nevertheless consistently bought out and transformed into luxurious apartments for new potential buyers. One example that illustrates this phenomenon is the building at 10 Łobzowska Street in Krakow's Piasek district. The townhouse, built at the start of the twentieth century, hides in its courtyard a freestanding masonry building that was originally used as an Atelier by Krakow's artists both before and after the Second World War (Fig. 1). The building, although small in scale, is characterised by high aesthetic value: it resembles a small church or chapel [8]. Due to the planned extension of the townhouse by its new owner, the Atelier is currently planned to be demolished, as it is not listed in the monuments register. In this and similar situations, due to the technology in which the building was constructed, the only solution that could protect it from demolition is its relocation [9]. This solution, although unpopular in Poland, has been used around the world already since the end of the sixteenth century [10]. This is a win-win situation. The city continues to naturally develop and the authentic structure is not demolished. Furthermore, due to the use of relocation, it can remain fully unchanged. 


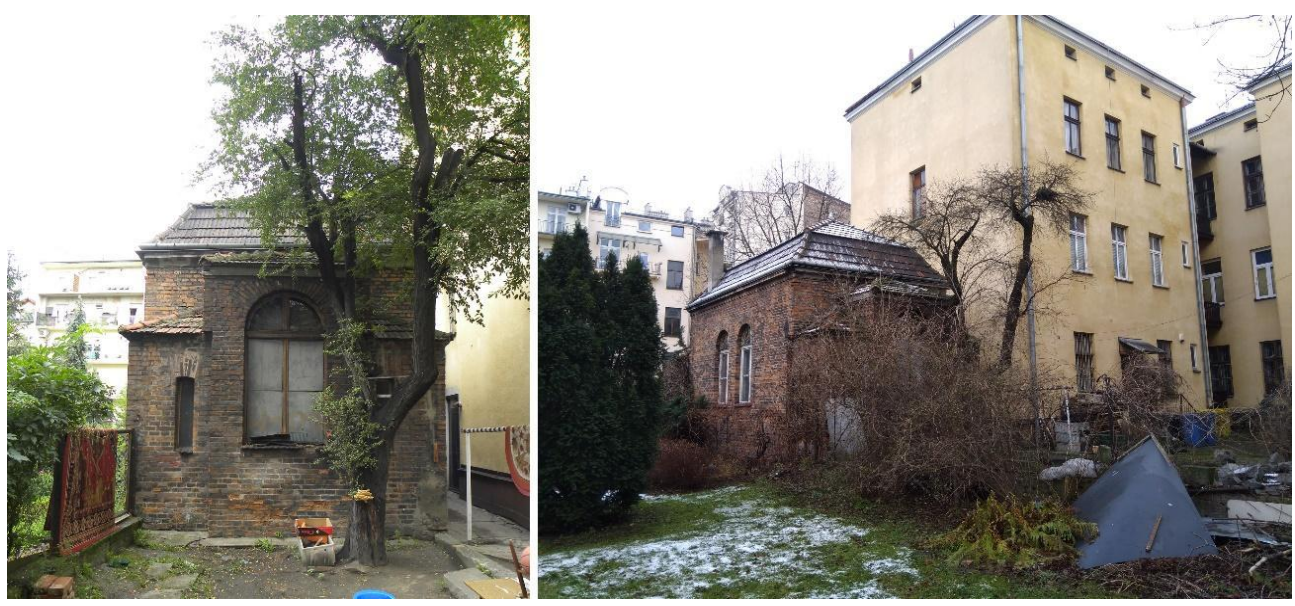

Fig. 1. Current view of the Atelier building and a tenement house at Łobzowska Street in Krakow.

\section{METHODS OF STUDY}

The idea behind the work is based on a case study of the on-going urban transformation of the Krakow district of Piasek. The research methods used by the authors included textual analysis of urban planning documents and their own work the conceptual design project of the relocation of the structure. The investigation was based on gathering historical and practical information by reviewing published materials, interviewing practitioners from multiple related disciplines, and personal observations. The idea behind the relocation project was based on archival studies, the aim of which was to uncover the value of the Atelier through the history of the Piasek district.

\section{RESULt AND DISCUSSION}

\subsection{Possibility of gentrification in a given area}

When discussing the phenomenon of gentrification and its consequences, one must first determine whether the process is currently ongoing within a given area. When analysing well-known cases of gentrification in global metropolises, such as Berlin's Kreuzberg district, where a cult district that was inhabited by young people and the creative class was turned into a major tourist destination [11], or the Mission District in San Francisco, which went from being home to a low-income Hispanic population to one of the most expensive places in the USA due to the steady influx of new residents employed in the high-tech sector that began in the 1990s [12], one can find spatial characteristics shared by such areas regardless of their geographical location [13]. These characteristics can be present either in groups, supplement each other, or clearly dominate the others. Such areas are typically characterised by proximity to historical city centres, a green area of metropolitan significance and, although they can bear signs of decay, they typically display aesthetic value associated with history or culture due to the presence of their original residents. 
Table 1. Analysis of the possibility of gentrification in a given area.

\begin{tabular}{l}
\hline Factor \\
$\begin{array}{r}\text { Distance to the city centre The district abuts the centre of Krakow's Old Town. The distance between } \\
\text { the townhouse at } 10 \text { Łobzowska Street and the Main Market Square is } 800\end{array}$
\end{tabular}

m.

Distance from a major green area

Aesthetic assets of the districts

Number of damaged buildings

Number of historical townhouses or buildings erected prior to 1950
It borders with Krakowski Park from the west and Planty Park, which separates it from the Old Town, from the east.

The district possesses highly valuable aesthetic assets, including pre-war buildings and good examples of Modernist architecture. It is very green as every city block has a green courtyard or internal garden.

There is an observable number of abandoned townhouses in the district, which are potentially attractive sites for new projects or remodeling measures (e.g., the townhouse at 10 Lobzowska Street).

The history of the district dates back to the fourteenth century and it is recognisable within the entire city, which developed particularly intensively during the start of the twentieth century. For this reason, most of its development is comprised of townhouses from before the Second World War.

Upon analysis of the factors listed above (Table 1), which indicate whether gentrification either can take or is taking place, it can be stated that the Piasek district is undergoing gentrification. Every city is unique, and to recognize the process of gentrification, one must perceive several factors together. The weight of each factor is different depending on the study case. There are no more or less important ones in terms of ongoing gentrification. In the case of Piasek district, the most significant ones are the short distance to the city centre and high esthetic assets of the district.

\subsection{The Case of Piasek District in Krakow}

Piasek is one of the oldest areas associated with the city of Krakow. At present, it is a district that directly borders on the Old Town. Only 200 years ago most of its territory comprised gardens and fields, while its development consisted of wooden rural houses, the suburban villas owned by wealthy residents of Krakow, and church buildings [14]. The end of the nineteenth century marked an intensive rise in development and the area began to transform into a housing district, which survived largely unchanged despite the Second World War.

Gentrification in Polish cities began only after 1989 [15]. This was closely associated with the country's political transformation, as previously, after the Second World War, social classes ceased to exist in an economic sense. In the $1990 \mathrm{~s}$, foreign capital began to flow into Poland, its population slowly gained affluence, and began to pay greater attention to the aesthetics of its surroundings.

Tracing the development of the Piasek district from the 1990s to the present, one can note that it has become a cultural site on the map of Krakow, a fashionable place to live while being inaccessible to average-income residents. It is now being renewed, revitalised, and is the site of new development projects (Table 2). 
Table 2. The process of gentrification in the Piasek district.

\begin{tabular}{|c|c|c|c|}
\hline Phenomenon & The 1990s & After 2000 & Present day \\
\hline $\begin{array}{c}\text { Demographic } \\
\text { changes }\end{array}$ & $\begin{array}{l}\text { Townhouses with a } \\
\text { stable number of } \\
\text { residents who have } \\
\text { lived there for many } \\
\text { years }\end{array}$ & $\begin{array}{l}\text { Due to the privatisation of } \\
\text { townhouses, poorer } \\
\text { residents are forced to leave } \\
\text { their apartments; start of the } \\
\text { trend of fixed-term } \\
\text { apartment rental to } \\
\text { students, the creative class } \\
\text { influx }\end{array}$ & $\begin{array}{l}\text { A small share of original } \\
\text { residents protected by } \\
\text { municipal law; the district is } \\
\text { inhabited by students and } \\
\text { affluent people; many buildings } \\
\text { are used as hotels } \\
\text { /hostels/apart- ments for fixed- } \\
\text { term rent }\end{array}$ \\
\hline $\begin{array}{l}\text { Examples of } \\
\quad \text { spatial } \\
\text { revitalisation }\end{array}$ & - & $\begin{array}{l}\text { Revitalisation of the major } \\
\text { streets, e.g., Karmelicka, } \\
\text { Krupnicza; revitalisation of } \\
\text { the area of Rajska Street; } \\
\text { the emergence of a new } \\
\text { cultural centre of Krakow, } \\
\text { revitalisation of a former } \\
\text { tobacco factory; the } \\
\text { emergence of a cult } \\
\text { gastronomic space }\end{array}$ & $\begin{array}{l}\text { The planned rerevitalisation of } \\
\text { the former tobacco factory; } \\
\text { closure of the cultural and } \\
\text { gastronomic space to make } \\
\text { space for a new luxurious } \\
\text { housing estate, revitalisation of } \\
\text { Karmelicka Street, Biskupi } \\
\text { Square, and many smaller areas }\end{array}$ \\
\hline New functions & - & $\begin{array}{l}\text { New cultural centre in the } \\
\text { district — the Lesser Poland } \\
\text { Garden of Art., the } \\
\text { construction of a University } \\
\text { branch - the Auditorium } \\
\text { Maximum, many new } \\
\text { service establishments }\end{array}$ & $\begin{array}{l}\text { Trend featuring the } \\
\text { establishment of luxurious } \\
\text { service facilities such as } \\
\text { spaces, expensive restaurants } \\
\text { with international cuisine } \\
\text { accessible only to affluent } \\
\text { district residents and tourists }\end{array}$ \\
\hline Decayed areas & $\begin{array}{c}\text { Neglected pocket } \\
\text { gardens, undeveloped } \\
\text { plots acting as waste } \\
\text { deposit sites, private } \\
\text { bus line stops, } \\
\text { unofficial parking } \\
\text { spaces, decayed area of } \\
\text { a former tobacco } \\
\text { factory }\end{array}$ & $\begin{array}{l}\text { Worsening street technical } \\
\text { condition, undeveloped } \\
\text { plots act as parking lots. }\end{array}$ & $\begin{array}{l}\text { Abandoned townhouses } \\
\text { awaiting renovation and an } \\
\text { undeveloped land plot that acts } \\
\text { as a parking lot: temporary } \\
\text { situations. }\end{array}$ \\
\hline $\begin{array}{l}\text { Building } \\
\text { renovations and } \\
\text { new projects }\end{array}$ & $\begin{array}{l}\text { Only necessary } \\
\text { townhouse maintenance } \\
\text { work due to worsening } \\
\text { technical condition }\end{array}$ & $\begin{array}{l}\text { Restoration of cult } \\
\text { buildings in the district, like } \\
\text { the Kamienica pod } \\
\text { Pająkiem by Talowski, the } \\
\text { Library, }\end{array}$ & $\begin{array}{l}\text { The general trend involving the } \\
\text { renovation of building facades, } \\
\text { numerous remodeling design } \\
\text { projects targeting existing } \\
\text { townhouses or new high- } \\
\text { standard design projects }\end{array}$ \\
\hline $\begin{array}{c}\text { General } \\
\text { aesthetics }\end{array}$ & $\begin{array}{l}\text { Many neglected } \\
\text { townhouses with visibly } \\
\text { deteriorated facades, } \\
\text { cases of nonland-scaped } \\
\text { greenery, generally } \\
\text { poor aesthetics }\end{array}$ & $\begin{array}{l}\text { A place undergoing } \\
\text { transformation; residents } \\
\text { begin to care for their } \\
\text { immediate surroundings; } \\
\text { overall good aesthetic } \\
\text { condition }\end{array}$ & $\begin{array}{l}\text { One of the greenest, well- } \\
\text { maintained, and attractive } \\
\text { districts of the city, very good } \\
\text { aesthetic when compared to the } \\
\text { rest of the city }\end{array}$ \\
\hline
\end{tabular}




\subsection{The direction of gentrification: human perspectives}

Krakow's population count showed very little signs of change during the turn of the century (Table 3). What has changed over the past 20 years is the increase in the number of the city's oldest residents and a marked decrease in the number of children and newborns.

Table 3. The population of Krakow by age

\begin{tabular}{|c|c|c|c|c|c|c|}
\hline Age / Year & 1998 & 2002 & 2010 & 2015 & 2017 & 2018 \\
\hline $0-19$ & 209552 & 161798 & 124445 & 112031 & 133131 & 136504 \\
\hline $20-39$ & 245464 & 242692 & 265607 & 249754 & 239196 & 234218 \\
\hline $40-59$ & 180047 & 240669 & 230111 & 191964 & 193976 & 195937 \\
\hline$>60$ & 110585 & 120250 & 167877 & 143270 & 201045 & 204410 \\
\hline total & 746627 & 758544 & 757740 & 761069 & 767348 & 771069 \\
\hline
\end{tabular}

Certainly, there are also several hundred thousand people who are not in the statistics. This number consists of about 200,000 students (in 1990, there were only 50,000) and a similar number of university graduates, 70,000 Ukrainian immigrants, as well as tourists flooding the city. Last year, Krakow was visited by 12 million tourists, and among foreign guests, there are those who come for several weeks or months. The number of universities increased from 12 in 1990 to 23 in 2010 [16]. This may explain an 11\% increase in the level of higher education among citizens in 2004-2011 (Fig. 2).

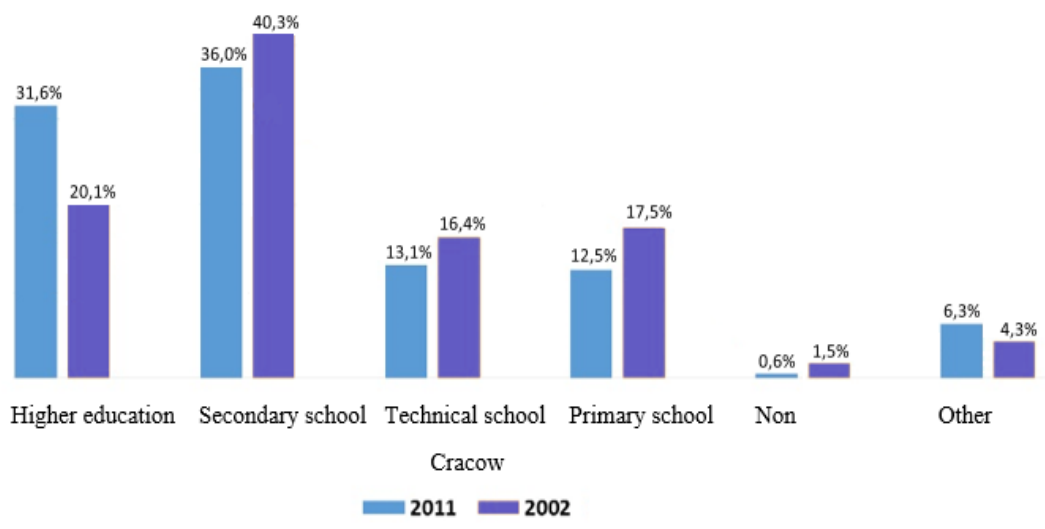

Fig. 2. Comparison the level of the education of inhabitants of Krakow.

The centre of Krakow is depopulating very quickly. In 1961, 52,000 people lived in the city centre, while in 2003, there were only 5 thousand [17]. This phenomenon shows that along with the natives of the neighborhood, the whole neighborhood is dying. Of course, new facilities are being erected, but they are not affordable to average-income people. Moreover, the middle class prefers to live in the suburbs as the city centre is full of tourists and nightlife[18]. According to a survey conducted on 152 residents of downtown Krakow in 2016 , the average age of a citizen is 44 . Students represent only $9 \%$ of the district's population. The largest part is the rich $60 \%$. On the other hand, 8 people out of 1000 have an eviction order due to lack of livelihood - this is a record in the scale of the entire city. In other districts, this number varies between 0.7-4.6.

The diversity of the social status of inhabitants generates areas characterized by the accumulation of social problems, such as poverty and crime. The problems of the district most often indicated by the inhabitants are communication and mobility (24\%), safety and 
nuisance phenomena and crime (21\%), health (18\%), and aesthetics (17\%) [19]. Referring to the data presented above, it is considered that gentrification in the Piasek district is ongoing and has not gone yet through a "full cycle".

\subsection{The idea of structure relocation}

Relocation is associated with moving a structure to a new location as a whole, without lowering its aesthetic and technical value. It is a process that is very difficult in technical terms and entails considerable costs. Although the first known procedure of this type was performed in 1598 in London, relocations are currently only used in special cases, when other methods of preventing a building's destruction cannot be applied. There are two relocation methods and the choice as to which of them should be used depends on the structural system of the building and its technical condition. Timber buildings can be dismantled. They can be disassembled and later reassembled again at a new location while preserving their original character. Masonry buildings typically need to be moved as a whole. They react poorly to disassembly, and attempts at performing it are associated with irreversible damage [20]. In such cases, after applying steel bracing frames, the structure is cut off from its foundations, lifted using actuators, and then moved to a new location.

Table 4. Analysis of the choice the method of structure relocation.

\begin{tabular}{|c|c|}
\hline Criteria & Atelier \\
\hline Structural system & Masonry structure \\
\hline Weight & $\begin{array}{c}15 \mathrm{t} \text {. The building is small in size, which allows the use of simple bracing } \\
\text { structures during relocation. }\end{array}$ \\
\hline $\begin{array}{l}\text { Distance from the } \\
\text { target site }\end{array}$ & $\begin{array}{c}29 \text { or } 59 \mathrm{~m} \text { in a straight line, depending on the chosen site- a small } \\
\text { distance between the original and target site. }\end{array}$ \\
\hline Technical condition & $\begin{array}{l}\text { The technical condition was assessed as poor. The building is dated to the } \\
\text { start of the twentieth century and has not been renovated since its } \\
\text { construction. }\end{array}$ \\
\hline
\end{tabular}

The Atelier located at Łobzowska Street, due to the factors described above (Table 4), should be relocated as a whole.

\subsection{Relocation-to be followed by?}

The Atelier building is to be relocated to a neighbouring plot, which is a garden owned by the Congregation of the Resurrection. This garden is located at the centre of a city block and is currently inaccessible to average-income residents of Krakow. After the relocation, this space is to undergo a revitalisation, and the building is to be subjected to adaptive reuse as an exhibition space [21]. Both the developer and the Congregation's leaders support the project. As the developer is aware of the historical and sentimental value of the Atelier, he agreed to financially support the process of translocation and regeneration of the whole garden after that. In return, the Congregation of the Resurrection agreed to provide the gate to the garden, open from the developer's plot side. The tenement house will then gain a view and its entrance to a semi-private garden in the very centre of the city. It will surely raise its price in the real estate market. As the entire structure of the Atelier building weighs only 15 tons, the moving process should not be very long or complicated.

The main design principle is to move the building of the historic Atelier in a straight line by either 21 or $59 \mathrm{~m}$, depending on the site development option chosen by the developer at a later stage of the project (Fig. 3). 
The approximate cost of both alternatives is $€ 100,000$. It is worth noting how small the cost appears in comparison to the cost of an apartment in this district, which estimates between $€ 4,000$ to $€ 5,000$ per $\mathrm{m} 2$. Apart from the difficulties and costs, relocating the building will bring numerous additional benefits that are unattainable by demolishing it [22]. Revitalising this space can provide an additional area with cultural and recreational assets for the residents of Krakow and tourists. There is a high demand for such spaces in Krakow [23]. All visitors will have the opportunity to rest in the public layout of the park and see the Atelier building. This space will be dedicated to organised cultural and religious events accessible to everyone.As noted previously, revitalisation can be one of the factors that contribute to gentrification. However, the city must continue to develop and do so in a natural manner regardless of the circumstances. With this relocation, at least one specimen of Krakow's beautiful architecture shall be saved from demolition.
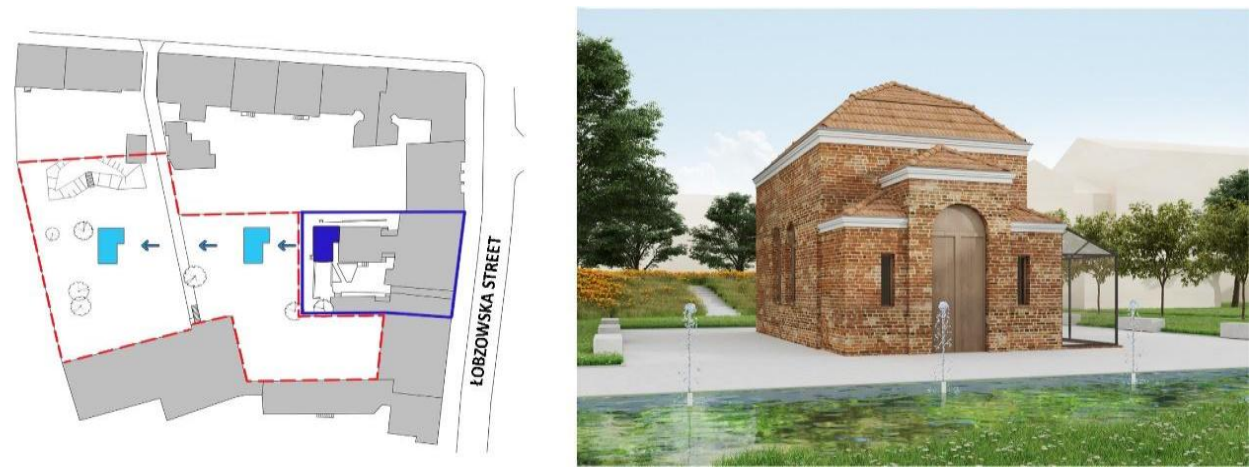

Fig. 3. On the left - schematic diagram of the two possible new locations of the building: the current place of the Atelier and a plot with tenement house marked in dark blue, possible locations marked in light blue; on the right - visualization of the regeneration project made by the author.

\section{Conclusion}

The development patterns that lead to gentrification are shaped by a complex array of private and public measures at the local, regional and national levels. The effect of gentrification on a person depends primarily on their social status. Gentrification is an instrument in the struggle against urban decay and an opportunity to make space attractive in the eyes of the middle class, real estate developers, and policymakers. On the other hand, it comes with an increase in living costs and the risk of eviction faced by poorer residents in the area.

The unique character of a district is often based on the beauty of its architecture. While space is subjected to aesthetisation, it sometimes happens that buildings that comprise original urban fabric are subjected to demolition. In certain respects, a neighbourhood that is gentrified can become a 'victim of its success'. The analyses that the authors performed and presented in this paper led to concrete conclusions as to how we can prevent this phenomenon that often accompanies gentrification.

Although costly and complicated, is in many cases relocating a building is the only way to save it from demolition, as in the case of the Atelier at Łobzowska Street in Krakow. This project is significant due to the historical considerations associated with the Atelier building, as well as the potential for future regeneration of this area. This creates new potential for revitalisation and new possibilities for its use, allowing the townhouse itself to be remodeled without the unnecessary destruction of valuable buildings in the Piasek district. This discussion is intended to sensitise the broadly understood users of this area, 
which can potentially be subjected to gentrification, to identify the risks borne by apparently positive measures intended to improve the use quality of a given place. In the context of raising awareness to ensure that one avoids situations in which interesting sites become forgotten, the Atelier case study could inspire discussion in the field of building relocation methods.

\section{REferences}

1. R. Glass, London: Aspects of Change. London: MacGibbon\&Kee (1964).

2. D. Groyecka, GentryfikacjaBerlina. Odżycianapodsłuchu do kulturycaffè latte. Gdańsk: Katedra (2014).

3. N. Smith, \& M. A. Le Faivre Class Analysis of Gentrification, In J.J. Palen\& B. London (ed.), Gentrification, Displacement, and Neighborhood Revitalization. Albany: State University of New York Press (1984).

4. L. Freeman, Urban Affairs Review Displacement or Succession: Residential Mobility in Gentrifying Neighborhoods, 40 (4) (2005).

5. Ł. Drozda, Uszlachetniajqcprzestrzeń. Jakdziałagentryfikacjaijaksięjamierzy, Warszawa: Instytut Wydawniczy Ksiqżkai Prasa (2017).

6. R. Atkinson, Urban StudiesMeasuring Gentrification and Displacement in Greater London37(1) (2000).

7. Jadach-Sepioło, A. Gentryfikacjamiast. Problemy Rozwoju Miast, 3, 67 (2007).

8. B. Podhalański, \& A. Połtowicz, Urban Development Issues Regeneration of a historic city block: the example of the relocation of the historic Atelier building to the cloister area of the Congregation of the Resurrection in Krakow63, 77-86 (2019).

9. N. Goblet, Moving Historic Buildings: One Means of Preservation, New York: Cornell University (2006).

10. W. Drozd, Civil and Environmental Engineering Reports Structure Relocation 29 (4), 176-184 (2019).

11. M. Schuhmann, Gentrification in Berlin Kreuzbergzwischen 1989 und 2000. Nordenstadt: GRIN Verlag (2013).

12. O. Howell, Making the Mission: Planning and Ethnicity in San Francisco. Chicago: University of Chicago Press (2015).

13. A.C. Helms, Journal of Urban Economics Understanding gentrification: an empirical analysis of the determinants of urban housing renovation 54 (2003).

14. K. Petrus, Czasopismo Techniczne Największeprzedmieście Krakowa. Zarysrozwojuprzestrzennego Garbar, Część II, 108(16), 153-163 (2011).

15. K. Stanilov, The Post-Socialist City. Urban Form and Space Transformations in Central and Eastern Europe after Socialism, Dordrecht: SpringerHousing trends in Central and Eastern European cities during and after the period of transition(2007).

16. M. Motak, Outline of the history of urban development of Krakow. Krakow: Cracow University of Technology (2018).

17. A. Chochorowska, History of Krakow in figures, Warszawa: Zakład Wydawnictw Statystycznych (2018).

18. M. Fulbiszewska, \& E. Lesińska, Mieszkańcy Krakowa: Opinienatematyżycia w mieście, Kraków: CEM (2013).

19. M. Chrzanowski, \& A. Strzebońska, Diagnozakrakowskichdzielnic 2016, Kraków: Centrum EwaluacjiiAnalizyPolitykPublicznychUniwersytetuJagiellońskiego (2016).

20. , Ł. Wesołowski, Wiadomości Konserwatorskie Translokacjaobiektówbudowlanych w aspekcieprzyczynimożliwościstosowana47, 40-51 (2016). 
21. Jäger, F.P. Birkhäuser ArchitectureOld New - Design Manual for Revitalizing Existing Buildings, Basel (2016).

22. Doratil, N. European Planning StudiesRevitalizing Historic Urban Quarters: A Model for Determining the Most Relevant Strategic Approach13(5), 749-772 (2004).

23. Zachariasz, A.

Krakow: WydawnictwoPolitechnikiKrakowskiejZieleńjakowspółczesnyczynnikmiastotwórczyzes zczególnymuwzględnieniemroliparkówpublicznych(2008). 